\title{
Sustainable Socio-Economic Development of Municipalities on the Example of the Concept of "Smart Cities"
}

\author{
N.M. Ulitskaya*, N.A. Ivanova, A.L. Mashkin, E.K. Telushkina, E.S. Gogolina \\ Moscow Automobile and Road Construction State Technical University (MADI), Moscow, Russia \\ *Corresponding author.Email: info@madi.ru
}

\begin{abstract}
In this article, the author conducted a study systematic comprehension and assessment of the real socio-economic efficiency of the prospects for the massive introduction in the municipalities of the Russian Federation of a complex of digital innovations in terms of monitoring the urban environment, management of life processes and economic activity, as well as a qualitative change in the level of citizen involvement in municipal governance processes. The widely known and actively implemented in the world and the Russian Federation, the functional concept of "smart cities" is currently characterized by the declaration of the principles of anthropocentrism, the qualitative growth of the technological effectiveness of infrastructure systems and processes, the "digital revolution" in the management of municipal resources of all types, progress in the organization of a safe and comfortable environment. residence. The Smart City project has been adopted and is being actively implemented. At the same time, the already implemented digital municipal initiatives do not allow to unambiguously assess their local and regional socio-economic efficiency from the standpoint of the actual contribution to the achievement of the goals of the strategic national and spatial development of the Russian Federation and its constituent regions and macro-territories. The best international practices of digital municipal development should be investigated for the fundamental dynamics of the nature of socio-economic interactions in the digital environment and adapted to the real situation of specific Russian municipalities and agglomerations.
\end{abstract}

Keywords: sustainable development of territories, socio-economic development, urban development, "smart city" concept, social digital environment.

\section{INTRODUCTION}

Materials and research methods are determined by the topic and the specifics of the tasks set, the solution of which requires an integrated approach. The set of scientific research methods used in writing a scientific article is represented by a system of general scientific, general economic and special research methods, techniques and developments in terms of regional and municipal economic measurements, monitoring of crisis problems and situations, ratings and socio-economic surveys, forecasting promising areas of digitalization of agglomeration processes and assessment of possible socio-economic effects from their applied implementation.

The fundamental theories of spatial and economic transformations and the possibilities of their initiation and controlled development are presented by the developments of E.M. Buchwald, A.G. Granberg, P.A. Minakira. The theoretical and methodological approaches of Russian researchers to the nature, features and possibilities of managing spatial and economic transformations, implemented in the form of research, are presented by the works of Yu.A. Anikina, A.M. Batalova, D.Yu. Bozharenko, M.V. Vladyka, Yu.V. Golchenko, A.K. Dorgushaova, A.S. Ilyina, M. Yu. Kazakova, E.L. Kornienko, S.I. Kutovoy, N.V. Lebedeva, E.A. Lubasheva F.A. Mambetova, E.R. Meteleva, A.A. Mirokhina, E.A. Podgornaya, O.K. Prokhorova, V.A. Semidotsky, E.A. Stryabkova.

Certain aspects of the problems and approaches to the management of spatial and economic transformations are presented in the scientific works of S.P. Balashova, E.A. Borkova (as part of a scientific group with V.A.Plotnikov, A.V. Prolubnikov, A.B. Titov), A.G. Volynsky, A.V. Gladilin and A.D. Ponomarenko, 
A.N. Golovkova, R.V. Eremina, S.V. Zakharova, E.I. Kostyukova in collaboration with A.N. Bobryshev and K.G. Mamedova, L.A. Kotova, M.A. Krotova, E.V. Kryukova, V.V. Lapkina, S.V. Levchenko, S.V. Makar, E.O. Mirgorodskaya, A.A. Mirokhina, D.L. Napolskikh, E.A. Platoshki-noy, Ya.P. Silin and E.G. Animitsa, A. Ya. Trotskovsky (in collaboration with I.V. Mishchenko), E.E., Shvakova, I.G. Shestakova, N.G. Yushkova.

The approaches of Russian authors to the problems of introducing the concept of "smart city" in the Russian Federation, implemented in the studies of A.G. Asatryan, D.M. Zhuravleva, Z.F. Ibragimova, S.G. Kamolova, V.M. Medvedev.

At the same time, the sources of competitive advantage and signs of a "smart city" as a "growth pole" and a source of positive spatial and economic transformations need to be clarified and systematized; the economic result of the applied implementation of the concept of a "smart city", new approaches are needed to implement the possibilities of attracting, rooting and integrating carriers of regional human and creative capital as the main social group of residents of the "smart city": with the prospect of highly efficient use in the economy of the city and the region. An independent direction of scientific research is the substantiation of the possibilities for the participation of "smart cities" in the composition of "smart urban agglomerations",commercial and municipal sector). Global and national methodological approaches to assessing the effectiveness of municipal digitalization processes from the standpoint of a socio-economic approach to managing the functioning and development of "smart" municipalities have certain reserves for modernization.

A "smart city" from the standpoint of a socioeconomic approach to managing the economy of municipalities is a special type of spatially localized socio-economic systems that allows realizing a system of local competitive advantages of an intellectual type based on the massive introduction of infrastructure and management technologies, methods and tools. The objective basis for the digitalization of the activities of the municipality and the growth of its digital maturity is the basic consensus between the population, corporate and municipal structures within it. It is in this case that the digitalization of certain areas of activity of the municipality or all of this activity can give a positive socio-economic effect for all municipal stakeholders.

\section{MODERN CONCEPT OF "SMART CITIES" AS PROGRESSIVE FORMS OF ECONOMIC TRANSFORMATION OF SUSTAINABLE MUNICIPAL AND REGIONAL DEVELOPMENT}

One of the priority national projects currently being implemented and combining the solution of a whole range of tasks in terms of housing and the urban environment, supported by new digital capabilities and technologies, is the Smart City project of digitalization of the urban economy, implemented by the Ministry of Construction, Housing and Utilities Russian Federation. According to the developers, this project initiative has at least three key areas of obtaining socioeconomic effects: [3, p. 34]

- saving all types of resources and increasing the rationality of nature management, focused on reducing the anthropogenic load on the territory of municipalities;

— increasing the efficiency of municipal management;

- increasing the competitiveness of cities as subjects of the processes of interregional and international competition for human and creative capital.

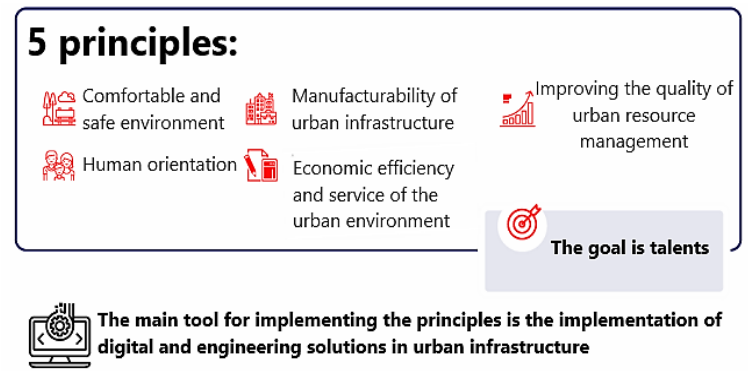

Figure 1 Key principles of the implementation of the "smart city" paradigm in the Russian Federation in 2019-2024.

The implementation of the project under consideration consists in scaling up "smart" municipal practices and open use of design data. [16, p. 28]

At the same time, the real socio-economic significance of "smart" cities as progressive forms of spatial and economic transformation and promising points of regional socio-economic development is currently at the stage of scientific research, much broader than individual digital infrastructure solutions.

Our present article attempts to generalize and comprehend the approaches, tools, methods and models accumulated by Russian researchers aimed at the productive use of the "smart city" format to increase the competitiveness of municipalities and regions, a systematic increase in management capabilities of the municipal and regional scale, the implementation of 
Table 1. Attributes of the implementation of power in the digital municipal environment.

\begin{tabular}{|c|c|}
\hline Sign & Characteristic \\
\hline Default openness & $\begin{array}{l}\text { 1. Polycentric open data; } \\
\text { 2. Large-scale interaction of citizen management systems; } \\
\text { 3. Culture of openness; }\end{array}$ \\
\hline Citizen in the spotlight & $\begin{array}{l}\text { 4. Interaction of citizens is a priority for governance; } \\
\text { 5. Development of various forms of democracy; }\end{array}$ \\
\hline Integrated network intelligence & $\begin{array}{l}\text { 6. Self-organization; } \\
\text { 7. Decentralization; } \\
\text { 8. Scale and connectedness; } \\
\end{array}$ \\
\hline Digital altruism & $\begin{array}{l}\text { 9. Joint creation of public goods; } \\
\text { 10. Societies based on community of data; } \\
\text { 11. The principle of reciprocity; }\end{array}$ \\
\hline Crowdsourcing & $\begin{array}{l}\text { 12. Diversified and free participation of citizens; } \\
\text { 13. Government support for civil initiatives; } \\
\text { 14. Liberalization. }\end{array}$ \\
\hline
\end{tabular}

targeted social economic programs and impacts. [8, p. 59]

The author of this article identified the attributes of the exercise of power in a digital municipal environment aimed at moving a resident (citizen) to the center of managerial attention, making wide use of the capabilities of artificial intelligence, understanding the importance of joint creation of digital public goods based on altruism and massive use of crowdsourcing procedures and technologies.

Note that the implementation of these attributes requires a qualitatively different level of digital municipal infrastructure than it is now, ensured by massive coverage of the territory of the municipality by digital telecommunication networks, the presence of a municipal data center and a supercomputer, as well as a significant scale of software adapted to the characteristics of a particular municipality. [12, p. 31]

The current stage of the digital transformation of the municipal management function is associated, first of all, with the development of new technological opportunities for the implementation of a complex of public services and the saving of time resources of entities focused onreceiving. A direct prospect for deepening digital transformation is the phases "State for a citizen" and "Fair government", within the latter it is assumed the possibility of predictive (prescriptive) municipal governance capable of providing a high standard of social stability and management technologies at the municipal level with the prospect of integration into the national digital system (which is currently associated with actual gaps that reduce the effectiveness of mass implementation of digital innovations. [6, p. 26]

We note a significant bias of existing research approaches to the study of "smart cities" as progressive forms of spatial and economic transformation and promising points of regional socio-economic development towards the technological basis, which, in our opinion, is associated with the awareness and commercialization of the possibilities of the "fifth information revolution »In the form of cross-border digital telecommunication opportunities, approaches, tools and technologies. [18, p. 78]

The managerial features of the digitalization of the activities of municipalities that are relevant for the Russian Federation are reduced to an increase in the involvement of the population of locations in sociopolitical processes and the full implementation of civil status and position as a full-fledged subject.

The socio-economic consequences of the digitalization of the activities of municipalities and the phenomenon of "smart cities" are at the initial level, although there is a large-scale demand and the need to identify and formalize the links between the level of digital maturity of modern Russian cities and their competitiveness, the efficiency of municipal economic systems, social efficiency in assessing rooted population and all categories of migrants.

\section{ECONOMIC AND SOCIAL OPPORTUNITIES OF THE "SMART CITY" AS A SOURCE OF PROGRESSIVE TRANSFORMATIONS OF MUNICIPALITIES}

The revealed insufficient level of elaboration of the issues of the socio-economic significance of "smart cities" as sources of positive spatial and economic deformations and development poles of promising agglomeration formations became the basis of the author's approach to expanding scientific ideas about the concept, tools and effectiveness of the implementation of the considered concept of municipal organization and management in the following logical sequences: [15, p. 82]

1. "Smart city" as a spatial growth point: sources of competitive advantage and signs of a growth point. 
2. Changes in the socio-economic model of the life of an individual in a "smart" digital environment as the main socio-economic result of the applied implementation of the "smart city" concept.

3. Regional human and creative capital as the main social group of residents of a "smart city": opportunities for attracting, rooting and integration with the prospect of highly efficient use in the economy of the city and the region.

4. "Smart urban agglomeration": the creation and growth of maturity based on the integrating targeted efforts of the stakeholders of the territory (population of cities - growth poles, population of suburbs and adjacent territories, commercial and municipal sector).

5. Methods for studying the level of perception by the population of the dynamics of digitalization of life processes and management in the cities of the region and the calculation of the regional index "IQ of cities". It should be emphasized that the objective basis for the digitalization of the activities of the municipality and the growth of its digital maturity is the basic consensus between the population, corporate and municipal structures within it. It is in this case that the digitalization of certain areas of activity of the municipality or all of this activity can give a positive socio-economic effect for all municipal stakeholders. Otherwise, the municipal space with a high level of digital maturity can become a "digital prison" in which any non-standard types of interests, activities or activities will be identified as unacceptable deviations and are subject to administrative or other forms of punishment.

We also note that the practice of functioning and development of truly advanced "smart cities", primarily Singapore as a "pole" of global competitiveness and a center of international social attraction, indicates the need for a global orientation and positioning of intelligent municipalities in the global economic and social space. Lack of openness within the national socioeconomic space, focus on domestic demand entails a significant bias in the socio-economic differentiation of the basic parameters of life and economic activity between cities - federal centers, cities - regional centers, other cities and adjacent territories. [5, p. 61]

Consistently satisfying the basic motives for attracting, rooting, integrating and interacting population groups and labor resources of the municipality with the rest of the local community, a "smart city" can become a national and international point of labor and entrepreneurial mobility, in which it is possible to achieve and increase the competitiveness of corporate sector structures, achieve and maintaining an effective socio-economic consensus between the stakeholders of the municipal space, rationalizing nature management and qualitative transformation of interactions "economic space - infrastructure - economic environment" towards sustainable development and reducing the negative consequences of anthropogenic pressure and economic activity. [10, p. 155]

The functional introduction of digital technologies should, in our opinion, be accompanied by an increase in the positive perception of the population of the municipality of the efforts being made, as well as an increase in the scale of its involvement in digital processes and the use of the possibilities of public opinion for their socio-ethical correction. Compulsory and already in demand at the current stage of socioeconomic and digital development of modern municipalities is digital security, which is relevant both for the population and for corporate structures and structures of municipal government. The end result of the "smart" development of the municipality, in our opinion, should be a new quality of labor resources of the local socio-economic system, associated with the concentration and highly productive labor and business activities of carriers of human and creative capital. [13, p. 44]

Additional opportunities for "smart" development are currently possessed by promising and developing agglomerations, in which smart cities can become local "growth poles" capable of ensuring the diffusion of digital innovations into the agglomeration economic and social space. The intelligent transport system of the agglomeration, which ensures high mobility of residents of municipalities and adjacent territories within the agglomeration, is capable of performing the function of a supporting frame, which provides the possibility of positive spatial and economic transformations in terms of the location of production facilities, areas of residence of the population, local and regional infrastructure facilities, centers of municipal and agglomeration management ... [1, p. 149] 
Table 2. "Smart city" as a spatial growth point.

\begin{tabular}{|c|c|}
\hline Signs of a spatial growth point & $\begin{array}{c}\text { The specifics of the "smart city" as an independent type of spatial growth points and a } \\
\text { source of positive spatial and economic transformations }\end{array}$ \\
\hline $\begin{array}{l}\text { 1. Systemic socio-economic } \\
\text { effect }\end{array}$ & $\begin{array}{l}\text { 1.1. It is connected with the implementation of the municipal consensus and the principles } \\
\text { of optimization of municipal management decisions according to the criteria for preventing } \\
\text { the deterioration of the positions of the stakeholders of the municipality (population - } \\
\text { residents, migrants, structures of the corporate and municipal sector); } \\
\text { 1.2. Saving all types of resources, increasing the rationality of nature management and } \\
\text { reducing the anthropogenic load on the territory and natural environment (space) of the } \\
\text { municipality; } \\
\text { 1.3. Development of intellectual and creative types of economic activity, competitive on a } \\
\text { national and international scale, and providing a qualitative increase in the income of the } \\
\text { stakeholders of the municipality (in comparison with the subjects of similar and adjacent } \\
\text { territories); }\end{array}$ \\
\hline 2. Investment attractiveness & $\begin{array}{l}\text { 2.1. Simplicity, transparency and speed (reasonable time) of procedures for initiating } \\
\text { economic activity (starting a business); } \\
\text { 2.2. Automation and reduction of resource intensity of the processes of interaction between } \\
\text { the stakeholders of the municipality in the course of local economic activity; } \\
\text { 2.3. The invariability of the conditions for conducting economic activity and an integrating } \\
\text { approach to the implementation of socially significant municipal investment initiatives; }\end{array}$ \\
\hline $\begin{array}{l}\text { 3. Stable autonomous demand for } \\
\text { products of basic production } \\
\text { (specialization) }\end{array}$ & $\begin{array}{l}\text { 3.1. Support for types of economic activities and entities focused on meeting foreign- } \\
\text { regional, national, international demand; } \\
\text { 3.2. Creation of competitive advantages of municipal stakeholders of an absolute and } \\
\text { relative nature; } \\
\text { 3.3. Targeted initiatives to attract human and creative capital to the economic environment } \\
\text { of the municipality; }\end{array}$ \\
\hline $\begin{array}{l}\text { 4. Priority and stimulation of the } \\
\text { cluster form of organizing } \\
\text { economic activity }\end{array}$ & $\begin{array}{l}\text { 4.1. A digital infrastructure that provides the ability to identify the presence and scope of } \\
\text { activities (including within the cluster and outside) of subjects - participants of cluster } \\
\text { formations; } \\
\text { 4.2. Support for centers of innovation clusters - universities, subjects of scientific and } \\
\text { intellectual activity; } \\
\text { 4.3. Targeted attraction of stakeholders with the potential for clustering the municipal } \\
\text { economic space; }\end{array}$ \\
\hline $\begin{array}{l}\text { 5. Cooperation and innovative } \\
\text { forms of economic interaction of } \\
\text { large, medium and small } \\
\text { businesses }\end{array}$ & $\begin{array}{l}\text { 5.1. Support for meso-level economic structures with the potential for municipal } \\
\text { localization (industrial parks); } \\
\text { 5.2. Support for intra-system demand on a municipal scale; } \\
\text { 5.3. Direct support for initiatives to import smart factors for municipal development; }\end{array}$ \\
\hline $\begin{array}{l}\text { 6. High level of infrastructure } \\
\text { provision of all types }\end{array}$ & $\begin{array}{l}\text { 6.1. Implementation of multimodal intelligent transport systems with the potential for local, } \\
\text { municipal and agglomeration development; } \\
\text { 6.2. Stimulating the development of the entire complex of municipal innovation } \\
\text { infrastructure focused on the reproduction of municipal and regional human and creative } \\
\text { capital; } \\
\text { 6.3. Massive implementation of digital infrastructure approaches, tools and technologies; }\end{array}$ \\
\hline $\begin{array}{l}\text { 7. Inclusion in the system of } \\
\text { intersectoral and interregional } \\
\text { economic and social relations }\end{array}$ & $\begin{array}{l}\text { 7.1. Realization of the role of the "growth pole" in promising and maturing agglomerations; } \\
\text { 7.2. Direct systematic support of initiatives to increase the value chains of the subjects - the } \\
\text { stakeholders of the municipality; } \\
\text { 7.3. Initiation, direct and indirect support of import-substituting economic initiatives on a } \\
\text { regional and national scale; }\end{array}$ \\
\hline $\begin{array}{l}\text { 8. Absolute competitive } \\
\text { advantages }\end{array}$ & $\begin{array}{l}\text { 8.1. Availability, cost, savings and } \text { secondary } \\
\text { basic resources of the main types of economic activity; } \\
\text { 8.2. Digital technologies for monitoring the processes of collection, sorting, } \\
\text { processing, recycling and disposal of all types of } \\
\text { garbage and waste; } \\
\text { 8.3. Targeted initiatives to attract and support the existing and promising (foreign-regional) } \\
\text { human and creative class in order to attract, take root and integrate into the economic and } \\
\text { social processes of the municipality; }\end{array}$ \\
\hline $\begin{array}{l}\text { 9. Special regime of economic } \\
\text { (economic) activity }\end{array}$ & $\begin{array}{l}\text { 9.1. Digital technologies and tools for registering and managing the activities of economic } \\
\text { entities, ensuring the saving of financial, investment and time resources (cloud registration, } \\
\text { accounting and reporting systems on the servers of banks of the financial systems of the } \\
\text { municipality); } \\
\text { 9.2. Digital Consumer and Digital Enterprise programs; } \\
\text { 9.3. Unified municipal tax on the results of economic activity of the stakeholders of the } \\
\text { municipality with the possibility of stimulating targeted socio-economic initiatives and } \\
\text { participation of stakeholders in the processes of municipal strategic and budget planning; }\end{array}$ \\
\hline $\begin{array}{l}\text { 10. Special treatment } \\
\text { regulation } \\
\text { (control) }\end{array}$ & $\begin{array}{l}\text { 10.1. Autonomous digital business environment; } \\
\text { 10.2. Intellectual center of municipal management with high digital maturity of basic } \\
\text { processes and procedures; } \\
\text { 10.3. Massive "digital" involvement of residents in municipal management and } \\
\text { development processes. }\end{array}$ \\
\hline
\end{tabular}


Table 3. Benefits of the functioning and development of stakeholders in a smart urban agglomeration (suggested by the author).

\begin{tabular}{|c|c|}
\hline Stakeholder group & Benefits and opportunities in smart urban agglomeration \\
\hline \multicolumn{2}{|c|}{ Population - residents and labor migrants } \\
\hline In cities - poles of growth & $\begin{array}{l}\text { Daily commuting labor migration for a distance of up to } 100 \text { kmtime up to } 1 \text { hour in one } \\
\text { direction. Saving costs for all types of resources. Safe and socially active life. Focus on } \\
\text { highly productive, intellectually intensive types of labor and business activities. Involvement } \\
\text { in municipal governance, activities and events. Implementation of joint initiatives for } \\
\text { functional development and spatial transformation in conjunction with the corporate and } \\
\text { municipal sectors. }\end{array}$ \\
\hline In adjacent territories & $\begin{array}{l}\text { Daily commuting labor migration for a distance of up to } 100 \text { kmtime up to } 1 \text { hour in one } \\
\text { direction. The possibility of receiving wages in the city - the pole of growth and its use within } \\
\text { the adjoining territories (with a lower cost of living). The possibility of resident migration to } \\
\text { the city - the center of the "smart" agglomeration. }\end{array}$ \\
\hline $\begin{array}{l}\text { Corporate } \\
\text { organizations }\end{array}$ & $\begin{array}{l}\text { The ability to separate operational processes and use labor resources of the required quantity } \\
\text { and quality in them. Saving the wage fund when using the labor resources of adjoining } \\
\text { territories and labor migrants. The growth of labor productivity and "new practical forms" } \\
\text { as a result of the work of workers in the subdivisions in the city - the pole of } \\
\text { growth. Implementation of joint initiatives for functional development and spatial } \\
\text { transformation together with the population and the municipal sector. }\end{array}$ \\
\hline $\begin{array}{l}\text { Municipal } \\
\text { Organizations }\end{array}$ & $\begin{array}{l}\text { Saving and saving all types of resources through the introduction of "smart" technologies in } \\
\text { the processes of municipal activities and management. Coordination of management } \\
\text { processes within the economic space of the agglomeration. Using the effects of polarization, } \\
\text { harmonization and alignment of the regional socio-economic space. Implementation of joint } \\
\text { initiatives for functional development and spatial transformation together with the public } \\
\text { and the corporate sector. }\end{array}$ \\
\hline $\begin{array}{l}\text { Subjects of the } \\
\text { infrastructure of a "smart" } \\
\text { urban agglomeration }\end{array}$ & $\begin{array}{l}\text { Process form of infrastructural support of economic and social subjects of the } \\
\text { agglomeration. Saving and saving all kinds of resources. Balanced development of new } \\
\text { adjoining and internal territories of the agglomeration. Effective interaction with regional } \\
\text { and non-regional infrastructure. }\end{array}$ \\
\hline $\begin{array}{l}\text { Subjects of the "smart" } \\
\text { control system for the } \\
\text { functioning } \\
\text { development of and } \\
\text { agglomeration }\end{array}$ & $\begin{array}{l}\text { Creation of a unified digital socio-economic environment of the agglomeration. Digital } \\
\text { twins of the population and organizations of the corporate and municipal } \\
\text { sectors. Operational monitoring and diagnostics of processes and problems of agglomeration } \\
\text { development. "Smart" environmental monitoring system. Quantitative models and forecasts } \\
\text { of the dynamics of agglomeration socio-economic processes. }\end{array}$ \\
\hline
\end{tabular}

\section{RUSSIAN NATIONAL RATING OF "SMART CITIES" AND THE POSSIBILITIES OF ITS USE IN MANAGING ECONOMIC TRANSFORMATIONS}

According to data provided in December 2020 year., the average level of digital transformation of a modern Russian city was estimated at 40.67 points with positive dynamics in the amount of $18.56 \%$ of the base 2018 year... and an increase in the number of participants in the rating (+ 12 municipalities in2019 year.).

We also note that the specialists of the Ministry of Construction of Russia, when calculating and interpreting the rating, operated with generalized assessments of all cities participating in the study, which made it possible to identify general trends in municipal digitalization in the studied sample, but reduced the representativeness in the application of average assessments regarding the digital and socio-economic problems of a particular city. [17, p. 106]
Among the most mastered areas for the growth of digital maturity in modern Russian municipalities is primarily

the sphere of public administration, including communication initiatives in terms of informing and involving citizens in the improvement and improvement initiatives. We also emphasize the growth in the efficiency of digital solutions at the municipal level in terms of tele-communication infrastructure, as well as increasing investment attractiveness.

Among the obviously problematic areas in which the progress of municipal digitalization is practically zero, are "Smart Housing and Utilities" and "Environmental Safety" (which, in our opinion, is connected with the need for more fundamental transformations of these problem areas in municipalities, which are not limited to the digitalization of existing and carried out functional and socio-economic processes).

It should be recognized that the most developed spheres of municipal processes have direct socioeconomic consequences:

- "Communication network infrastructure", within which the cities - participants of the study achieved an 
average score of 9.15 out of 10 with a positive dynamics of $2.91 \%$ and the presence of 131 municipalities in which the calculated sub-index exceeded the average value for the sample;

- "Smart city transport", within which the cities participants of the study achieved an average score of 2.8 out of 10 with a positive dynamics of $3.73 \%$ and the presence of 142 municipalities in which the calculated sub-index exceeded the average value for the sample.

At the same time, the direction "Intelligent environmental safety systems" was one of the least popular areas for digitalization (recall that in the global ranking, the state and air pollution were among the representative parameters of observation and assessment, more than $50 \%$ of respondents stated their importance). In this area of municipal digitalization, the average score was 0.03 out of 10 with no positive dynamics and the presence of 6 municipalities (out of 203 ) in which digital maturity in this area exceeded the average level. [19, p. 62]

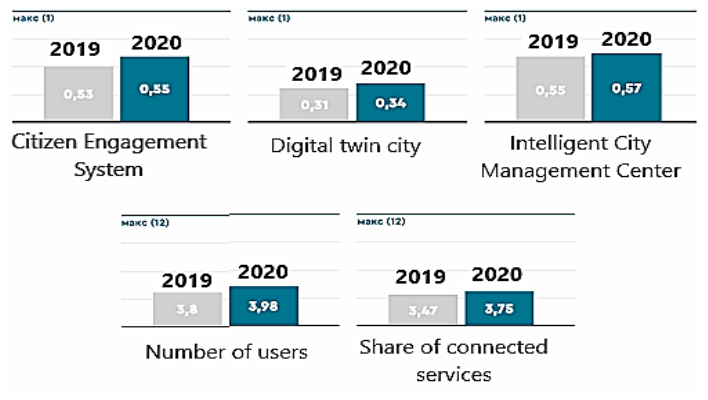

Figure 2 The main forms of digital innovations in the field of urban management of "smart cities" of the Russian Federation in 2019-2020. ("IQ of cities" of the Ministry of Construction of the Russian Federation).

The most positive digital practices of municipal governance in 2019-2020 there were systems for involving citizens in the processes of joint activity and expression of will, as well as the modernization of the activities of intellectual centers capable of ensuring the digitalization of urban management processes. [2, p. ten]

The main forms of digital innovations in the field of "Smart housing and communal services" of "smart cities" of the Russian Federation in 2019-2020. are presented in Figure 3.

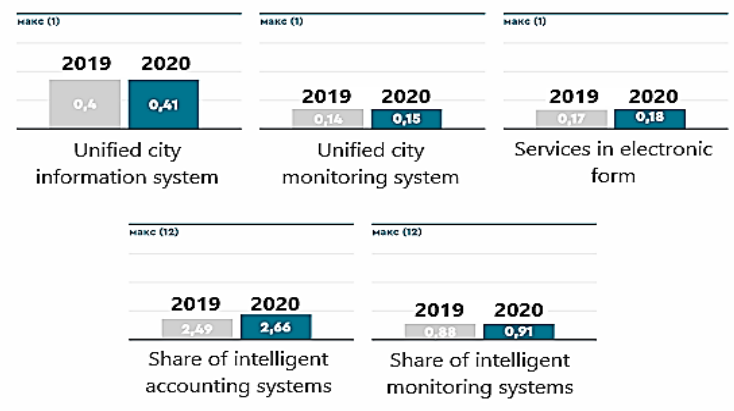

Figure 3 The main forms of digital innovations in the field of "Smart Housing and Utilities" in 20192020. ("IQ of cities" of the Ministry of Construction of the Russian Federation).

Let us note a promising direction for the growth of digital maturity of municipal systems of housing and communal services, associated with the introduction of intelligent accounting and monitoring systems, which have demonstrated a significant increase in the scale of implementation in 2020 year... and provided an overall positive growth trend for urban IQ in this functional area.

At the same time, massive digitalization of housing and communal services in terms of the use of smart meters still remains in the plans of municipalities, since it requires rather large investments, and is currently usually applied to debtors and entities with suspiciously low volumes of utilities consumption. [9, p. 27]

The main forms of digital innovations in the field of "Innovation for the urban environment" of "smart cities" of the Russian Federation in 2019-2020. are presented in Figure 4.

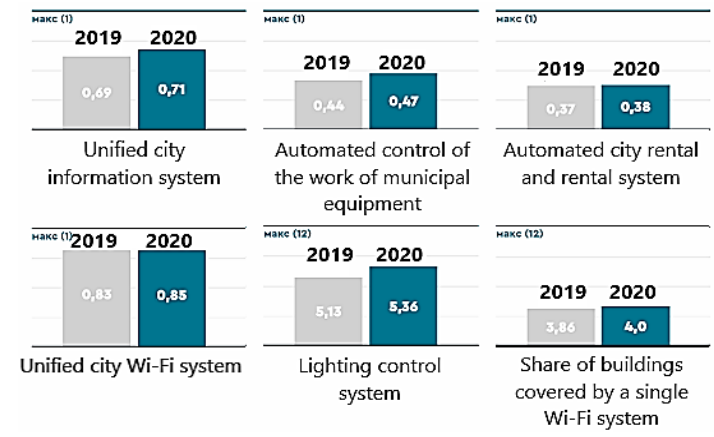

Figure 4 The main forms of digital innovations in the field of "Innovation for the urban environment" in 20192020. ("IQ of cities" of the Ministry of Construction of the Russian Federation1).

This area demonstrated a steady growth in the digital maturity of municipalities, especially in terms of the presence of a unified urban Wi-Fi system and outdoor lighting control systems (ASUNO), although the growth in the coverage of the territories of "smart" Russian cities by these intelligent systems had significant growth reserves. 
The main forms of digital innovations in the field of "Urban transport" of "smart cities" of the Russian Federation in 2018-2019. are presented in Figure 5.

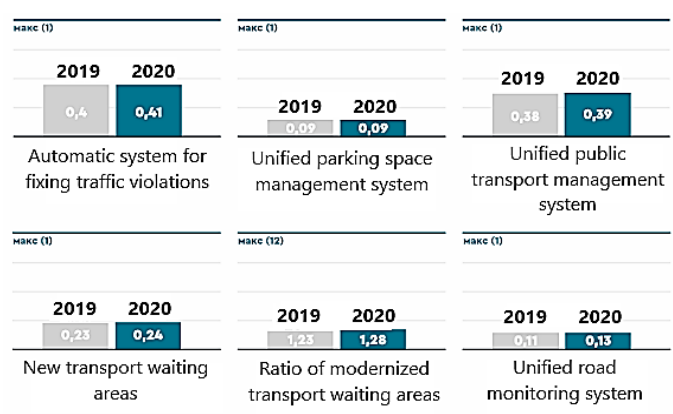

Figure 5 The main forms of digital innovations in the field of "Urban transport" in 2018-2019. ("IQ of cities" of the Ministry of Construction of the Russian Federation).

Intellectualization of the processes of urban transport activity was a very promising direction of the current level of development of Russian "smart" cities: significant savings in public expenditures and an increase in the scope of responsibility of car drivers ensured the development of automated systems for fixing traffic violations, which in federal cities significantly contributed to a decrease in the number of administrative offenses and increased revenue in the form of fines. At the same time, global "smart" cities have in their asset digital system solutions in terms of public transport management, ensuring the functioning of municipal transport in systems with a diameter of up to $100 \mathrm{~km}$ and the speed of crossing the diameter up to 2 hours (for example, Munich, 11th place in the Smart City Index 2021). [14, p. 56]

In Russian cities of a much smaller scale, the problems of digitalization of transport activities are even more potential from the standpoint of reducing travel time, fuel consumption and the number of road accidents, as well as saving the transport budget of citizens as part of regular household expenses.

The operational results of the growth of the digital maturity of Russian cities based on the intellectualization of urban transport management systems are presented in Figure 6.

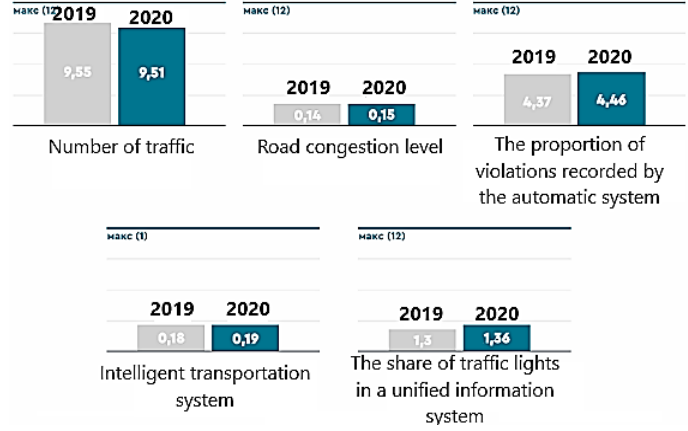

Figure 6 Operational results of the growth of digital maturity of Russian cities based on the intellectualization of urban transport management systems in 2018-2019. ("IQ of cities" of the Ministry of Construction of the Russian Federation).

It should be emphasized that digital transport solutions by themselves are not capable of providing a complete and comprehensive solution to municipal transport problems and situations that are associated, among other things, with factors not covered by digitalization. $[7$, p. 70$]$

At the same time, for example, the given indicator of the level of road accidents still showed a certain decrease, however, against the background of an increase in road congestion and an increase in digital recording of traffic violations.

At the same time, the experience of cities - federal centers with the practice of full coverage of digital systems for fixing municipal transport space allows us to positively characterize the prospects for increasing digital maturity and smaller municipalities in this direction, to ensure the principle of impartiality of fixation and full administrative coverage of penalties for traffic offenders (regardless of their positions and opportunities for communication with traffic police inspectors). [4, p. 153]

It should be noted that there is a steady growth in the provision of municipal spaces with digital mobile telecommunication capabilities. Taking into account the prospects for the implementation of $5 \mathrm{G}$ and $6 \mathrm{G}$ networks, the Russian Federation and its cities can achieve sustainable competitive advantages in the digital communication environment, creating in this functional area sustainable prerequisites for the growth of digital maturity of municipalities and related promising information, communication and management capabilities.

\section{RESULT}

A significant bias has been accumulated and is observed in the existing research approaches to the study of "smart cities" as progressive forms of spatial and economic transformation and promising points of 
regional socio-economic development towards the technological basis, which, in our opinion, is associated with the awareness and commercialization of the possibilities of the "fifth information revolution "in the form of cross-border digital telecommunication opportunities, approaches, tools and technologies.

The managerial features of the digitalization of the activities of municipalities that are relevant for the Russian Federation are reduced to an increase in the involvement of the population of locations in sociopolitical processes and the full implementation of civil status and position as a full-fledged subject.

\section{CONCLUSION}

The revealed insufficient level of elaboration of the issues of the socio-economic significance of "smart cities" as sources of positive spatial and economic deformations and development poles of promising agglomeration formations became the basis of the author's approach to expanding scientific ideas about the concept, tools and effectiveness of the implementation of the considered concept of municipal organization and management in the following logical sequences:

1. "Smart city" as a spatial growth point: sources of competitive advantage and signs of a growth point.

2. Changes in the socio-economic model of the life of an individual in a "smart" digital environment as the main socio-economic result of the applied implementation of the "smart city" concept.

3. Regional human and creative capital as the main social group of residents of a "smart city": opportunities for attracting, rooting and integration with the prospect of highly efficient use in the economy of the city and the region.

4. "Smart urban agglomeration": the creation and growth of maturity based on the integrating targeted efforts of the stakeholders of the territory (population of cities - growth poles, population of suburbs and adjacent territories, commercial and municipal sector).

5. Methods for studying the level of perception by the population of the dynamics of digitalization of life processes and management in the cities of the region and the calculation of the regional index "IQ of cities".

Let us emphasize the necessity and relevance of considering the functional capabilities of "smart cities" in the context of socio-economic research and assessment methodology focused on forecasting and assessing the consequences of spatial and economic transformations. The "smart city" as a socio-economic phenomenon of the "digital economy" should, in our opinion, provide a real increase in efficiency, satisfaction and positivity in the activities of all key stakeholders of the municipal space, primarily the population, as well as corporate and municipal structures.

\section{REFERENCES}

[1] A.A. Avetyan, The concept of Smart City as a strategy for urban management. Region and World, 11(6) (2020) p. 149.

[2] G.I. Aleeva, The concept of "Smart City" in the segment of the "green economy". Ila Sistem, 1(14) (2020) p. 10.

[3] I.A. Grankina, World experience in developing a city strategy taking into account the concept of SMART CITY. Economics and management of control systems, 2(40) (2021) p. 34.

[4] S.G. Eremeev, SMART-CITY: in search of conceptualization. Power, 27(1) (2019) p. 153.

[5] S.G. Eremeev, Strategic planning in the implementation of the concept of SMART CITY. Power, 29(2) (2021) p. 61.

[6] V.V. Ivanov, R.K. Nurmukhametov, About the concept of "Smart City" (SMART CITY): discussion issues. Management and business administration, 4 (2019) p. 26.

[7] S.A. Ivanova, SMART CITY in the Arctic: an overview of modern research and practice. Issues of innovative economics, 11(1) (2021) p. 70.

[8] O.O. Komarevtseva, An aggregated model for assessing the readiness of the economy of a municipal entity to develop in accordance with the concept of SMART CITY. News of the South-West State University, 11(2) (2021) p. 59.

[9] O.O. Komarevtseva, The introduction of Smart City technologies into the management mechanism of the municipal formation. Open education, 25(1) (2021), p. 27.

[10] O.V. Logvinovskaya, Approaches to the formation of the IQ index of cities. Bulletin of the South Ural State University, 20(2) (2020) p. 155.

[11] V.N. Loginov, I.A. Bychkovsky, G.S. Surnov, S.I. Surnov, SMART MONITORING is a technology for remote monitoring of electricity, water, heat and gas consumption in SMART CITY, MIPT TRUDY, In: proceedings of the Moscow Institute of Physics and Technology (National Research University), 2020, p. 99.

[12] A. Makarov, B. Zhunusov, E. Nazmiev, Modern concept of city development in the framework of the project "SMART CITY". Regional economic j., 1(30) (2021) p. 31. 
[13] N.S. Moshenchenko, B.Yu. Zhurakovsky, SMART CITY standards. Actual scientific research in the modern world, 2-1(58) (2020) p. 44.

[14] D.L. Napolskikh, Transformation of the economic space of the Volga region based on the clustering of production. Economy and Entrepreneurship, 3 (2021) p. 56.

[15] M.A. Pastukhov, E.S. Nosik, Foreign experience of using the SMART CITY model. "Scientific works of KubGTU", Electronic network polythematic j., 8 (2020) p. 82.

[16] Ya.P. Silin, E.G. Animitsa, Evolution of the paradigm of the regional economy. J. of new economy, 21(1) (2020) p. 28.

[17] D.R. Tarasov, The concept of Smart City (on the example of European cities), In: student science and the XXI century, 17 2-2 (20) (2020) p. 106.

[18] E.M. Tausend, Smart cities: big data, civilian hackers and the quest for a new utopia, p. 78 (2019).

[19] V.P. Shumilin, Smart city transport as one of the elements of the Smart City project. Management of road safety activities: state, problems, ways of improvement, 1(3) (2020) p. 62. 